\title{
The Effects of the FIFA 11+ and Self-Myofascial Release Complex Training on Injury, Flexibility and Muscle Stiffness of High School Football Players
}

\author{
Young-In Choi ${ }^{1}$, Houng-Sik Choi ${ }^{2}$, Tack-Hoon Kim², Kyu-Hwan Choi ${ }^{3}$, Gyoung-Mo Kim ${ }^{4}$, Jung-Suk Roh ${ }^{2}$ \\ 'Department of Physical Therapy, The Graduate School, Hanseo University, Seosan, Republic of Korea; ${ }^{2}$ Department of Physical Therapy, Hanseo \\ University, Seosan, Republic of Korea; ${ }^{3}$ Department of Physical Therapy, Ansan University, Ansan, Republic of Korea; ${ }^{4}$ Department of Physical \\ Therapy, Daejeon Health Institute of Technology, Daejeon, Republic of Korea
}

Purpose: The purpose of this study was to investigate the effects of complex training on injury, flexibility, and muscle stiffness in high school male football players.

Methods: A total of 60 football players were included in the study and were divided into three groups viz. the complex training group (CTG), 11+ training group $(11+\mathrm{TG})$, and traditional training group (TG). Injuries were recorded based on the prospective investigation method after starting the study, and the flexibility and muscle stiffness of the subjects were evaluated.

Results: The research results showed that the injury rate per match was significantly lower in the CTG and $11+$ TG than the TTG. In the CTG, the flexibility of the hamstrings significantly increased and the stiffness of the rectus femoris (RF), biceps femoris (BF), and tensor fascia latae (TFL) muscles significantly decreased $(p<0.05)$. In the $11+T G$, the stiffness of the RF significantly decreased $(p<0.05)$. In the $\Pi G$, the flexibility of the hamstrings significantly increased $(p<0.05)$. Hamstring flexibility showed a significantly higher increase in the CTG and TTG compared to the $11+T G(p<0.05)$. Also, the stiffness of the RF and TFL muscles showed a significantly higher decrease in the CTG compared to the $11+T G$ and TTG $(p<0.05)$. The stiffness of the BF muscles too showed a more significant decrease in the CTG compared to the $\Pi G(p<0.05)$.

Conclusion: The complex training method of the Fédération International de Football Association (FIFA) 11+ and self-myofascial release (SMFR) as a warm-up program, prevent injuries, enhance flexibility, and lower muscle stiffness of football players in high school. Thus, it is necessary to ensure the widespread use of the complex training program by instructors and players under the supervision of the Korea Football Association (KFA), given its reliability in preventing injuries and improving the performance of football players.

Keywords: Football, Athletic injuries, Warm-up exercise

\section{서 론}

축구는 부상 위험도가 매우 높은 운동종목이다. 국제축구연맹이 보 고한 월드컵 대회의 경기당 부상률(injury rate per match)·경기당 결장 부상률(time-loss injury rate per match)·부상 호발부위를 살펴보면, 1998년 프랑스 월드컵 2.40회·조사미실시·무릎(23\%)·넓적다리(20\%), 2002년 한국/일본 월드컵 2.67회·1.67회·넓적다리(18\%)·아래다리 (17\%), 2006년 독일 월드컵 2.27회·1.51회·아래다리(21\%)·발목(17\%), 2010년 남아프리카공화국 월드컵 2.02회·1.29회·넓적다리(29\%)·아래 다리(15\%), 2014년 브라질 월드컵 1.68회·0.97회·넓적다리(25\%)·머리/ 얼굴/목(18\%)이었다.1
축구선수는 상대와의 신체접촉 유무에 따라 접촉성 부상(contact injury) 및 비접촉성 부상(non-contact injury)이 초래될 수 있다. 접촉 성 부상은 심판의 엄정한 규칙적용과 선수의 기술능력 향상 및 페어 플레이 정신 고취를 통해 감소될 수 있지만, 비접촉성 부상은 철저한 준비과정을 통해 예방될 수 있다. ${ }^{2}$ 이때 효과적인 예방전략을 수립하 기 위해서 선행되어야 할 것이 축구선수의 부상 위험요인에 대한 탐 색으로 내재적 및 외재적 요인이 있다. 내재적 요인은 근력, 균형, 피 로, 유연성 등과 같이 후천적인 노력에 의해 수정 가능한 것들을 의미 하고, 외재적 요인은 성별, 연령, 인종 등과 같이 수정 불가능한 것들 을 지칭한다. ${ }^{34}$ 축구선수의 부상방지에 책임이 있는 국제축구연맹은 산하에 의료 평가 및 연구 센터(FIFA Medical Assessment and Research
Received Jan 20, 2022 Revised Feb 11, 2022

Accepted Feb 15, 2022

Corresponding author Jung-Suk Roh

E-mail rrohjs@hanseo.ac.kr
Copylight (C2022 The Korean Society of Physical Therapy

This is an Open Access article distribute under the terms of the Creative Commons Attribution Non-commercial License (https:// creativecommons.org/license/by-nc/4.o.) which permits unrestricted non-commercial use, distribution, and reproduction in any medium, provided the original work is properly cited. 
Centre, F-MARC)를 설립하고, 외부 기관인 오슬로 스포츠 외상 연구 센터(Oslo Sports Trauma Research Center) 및 산타 모니카 정형·스포 츠 의학 연구재단(Santa Monica Orthopaedic and Sports Medicine Research Foundation)과 협력하여 역동적 웜업 운동인 피파 11+ (FIFA $11+)$ 프로그램을 개발하였다. 축구선수의 부상예방을 위하여 제작 한 피파 $11+$ 프로그램은 세 개의 훈련영역으로 구분되며, 달리기, 균 형훈련, 코어운동, 하지근력운동, 플라이오메트릭 등의 요소가 포함 되어 있다.

근래에 들어 축구과학 분야에서는 피파 $11+$ 프로그램의 효용성을 검증하기 위하여 다각적인 견해를 가지고 연구가 이루어졌다. 1 시즌 동안 125 개 팀의 청소년 여자축구선수 2,540 명을 대상으로 실시한 연 구, ${ }^{5}$ 개월 동안 나이지리아 청소년 남자축구선수를 대상으로 실시 한 연구, ${ }^{6}$ 전미대학체육협회 디비전 I · II 리그에서 활동하고 있는 61 개 팀의 남자선수 1,525 명을 대상으로 한 연구를 통해 피파 $11+$ 프로 그램이 부상예방에 효과적임을 확인할 수 있었다. 또한 넙다리뒤근 육/넙다리네갈래근육의 근력비율"과 벽 발리. 수직점프. 일리노이 민 첩성 검사에서 유의한 효과를 보고하였으며, ${ }^{9}$ 유소년 축구선수의 역 이동 점프와 민첩성 달리기, ${ }^{10}$ 청소년 남자축구선수의 좌전굴, 드리 블, 수직점프, 일리노이 민첩성, 36.6미터 스프린트, 보스코 역이동 점 프, ${ }^{11}$ 그리고 대학축구선수의 수직점프와 20미터 스프린트 검사에 대 해서도 통계학적인 유의성을 나타냈다.'

근막이완(myofascia release)은 운동 후 재생 및 회복에 중점을 둔 치료적인 기법으로 알려져 있었지만, 최근 운동선수 사이에서 시합 전 수행력을 향상시키는 웜업 기법으로 부각되고 있다. ${ }^{13}$ 근막이완 방 법으로는 폼롤러를 사용하여 전신근육을 롤링.압박하는 자가근막 이완기법으로 연부조직에 대한 압박력 생성을 통해 뼈대근육 및 결 합조직의 기능부전이 해결될 수 있다.13.14 지금까지 보고된 자가근막 이완의 효과는 유연성 증가, 가동성 향상, 조직사이의 유착 및 반흔조 직 감소, 근육불균형 교정, 근육경련 감소, 통증 감소, 동맥경직도 감 소, 혈류공급 증가, 부교감신경활성 증가, 혈관 내피세포 기능향상, 근 육긴장 이완, 근육경직도 감소 등이 있으며, 이러한 효과는 인체의 다 양한 기관에 일시적 및 장기적 영향을 미치는 것으로 알려져 있다.15 이와 같은 다수의 장점 때문에 근력 및 컨디션닝 영역에서는 자가근 막이완이 웜업 프로그램으로써 우수한 평가를 받아 점차 확산되고 있는 것이 세계적인 추세이다.13
이처럼 피파 11+ 프로그램과 자가근막이완은 축구선수에게 효과 적인 웜업 방법으로 간주되고 있지만, 국내에서는 이와 관련된 연구 가 매우 부족할 뿐만 아니라 선수기량 성장에 주요 보고라 할 수 있 는 아마추어 현장에서 활용한 사례를 찾기가 어려운 실정이다. 따라 서 프로그램의 확산을 위해 실제 축구선수를 대상으로 효용성을 검 증할 필요가 있어 본 연구를 실시하였다.

서로 다른 운동요소의 상호보완 작용이 상승효과를 발휘할 수 있 기 때문에 최근 운동관련 중재연구에서는 복합훈련을 자주 실시하 고 있다. ${ }^{16}$ 이러한 견해에 기초하여 상이한 운동요소를 가지고 있는 피파 $11+$ 와 자가근막이완의 통합은 선행연구에서처럼 개별 적용한 것 보다 추가적인 이점이 있을 것으로 판단된다. 이에 본 연구는 피파 $11+$ 와 자가근막이완 복합훈련이 고등학교 축구선수의 부상, 유연성, 근육경직도에 미치는 영향을 규명하여 현장에서 적용 가능한 효과 적인 훈련 프로그램을 제시하고자 하였으며, 이를 검증하기 위한 비 교집단으로 $11+$ 훈련 및 일반훈련 집단을 두었다.

\section{연구 방법}

\section{1. 연구대상}

본 연구의 대상자는 2018 전국고등축구리그에 참가한 3 개팀 소속 선 수 60 명으로 하였다. 연구집단 간 오염변인을 최소화하기 위해 선수 개인이 아닌 팀으로써 복합훈련 집단(complex training group, CTG), $11+$ 훈련 집단(11+ training group, 11+TG), 일반훈련 집단(traditional training group, TTG)에 20명씩 무선 배정하였다. 모든 대상자는 5년 이상의 선수경력을 가지고 규칙적으로 팀훈련에 참가하였으며, 3 개 월 이내 다리의 부상병력이 없었다. 연구가 시작되기 이전 대상자에 게 목적, 절차, 내용을 상세히 설명한 후 자발적인 참여의사와 동의서 를 받았으며, 요청할 경우 언제든지 실험참가를 중단할 수 있도록 하 였다. 시즌 동안 각 집단의 공식 및 연습 경기 일정은 유사하였으며, 숙소생활을 하는 관계로 선수들의 하루일과 패턴은 규칙적인 편이었 다. 현재 센터 및 전문가에게 개인훈련을 받거나 4 년 이내 피파 $11+$ 프 로그램을 경험하였다면 본 연구에서 제외하였다. 연구 대상자의 일 반적 특성은 Table 1과 같다.

Table 1. Physical characteristics of subjects

\begin{tabular}{|c|c|c|c|c|c|}
\hline Group & Age (yr) & Height (cm) & Weight (kg) & $\mathrm{BMI}\left(\mathrm{kg} / \mathrm{m}^{2}\right)$ & Career (yr) \\
\hline CTG $(n=20)$ & $18.3 \pm 0.7$ & $176.8 \pm 3.6$ & $68.3 \pm 4.3$ & $21.8 \pm 0.9$ & $7.2 \pm 1.3$ \\
\hline $11+T G(n=20)$ & $18.4 \pm 0.7$ & $176.1 \pm 6.4$ & $68.6 \pm 6.7$ & $22.1 \pm 1.3$ & $7.3 \pm 1.1$ \\
\hline TTG $(n=20)$ & $18.1 \pm 0.8$ & $175.7 \pm 3.5$ & $68.9 \pm 4.8$ & $22.3 \pm 0.9$ & $7.1 \pm 1.2$ \\
\hline
\end{tabular}

Mean \pm SD.

CTG: complex training group, 11+TG: 11+ training group, TTG: traditional training group, BMl: body mass index. 


\section{2. 측정방법 및 도구}

1) 부상

12 주 동안 발생한 축구선수의 부상실태는 전향성 조사방식으로 확 인하였다. 팀 관계자 중 한 명의 작성담당자가 기록방법에 대해 사전 교육을 받았으며, 1 주 마다 기록지를 회신하였다. 공식 및 연습 경기 도중 발생한 신체적 불편함으로 인해 병원진료 ${ }^{17}$ 를 받거나 다음 경기 에 결장할 경우 부상이라 규정지었으며, 병원진료는 medical attention (MA), 경기결장은 time loss (TL)라 기입하였다. 경기당 부상률은 공식경기와 연습경기를 더한 횟수에서 부상빈도를 나누어 계산하였 고, 전체부상 및 결장부상으로 구분하여 제시하였다. 부상정도는 부 상 이후 결장기간에 따라 분류할 수 있다. 0 일은 무결장(no absence), 1-3일은 최소(minimal), 4-7일은 경미(mild), 8-28일은 중등(moderate), 28 일 이상은 심각(severe), 그리고 경기장 복귀가 불가능한 경우 선수 경력 종료(career ending)라 한다. ${ }^{18}$

\section{2) 유연성}

넙다리뒤근육의 유연성은 센서가 내장된 InBody u-Town 건강체력 검사장비 위에서 앉아 숙이기 방법으로 측정하였다(Inbody, Korea). 대상자는 다리를 뻗고 앉은자세를 취한 다음 양발을 발판에 밀착시 켰으며, 무릎이 구부러지지 않도록 주의하였다. 검사자의 신호에 따 라 양팔의 수평을 유지하며 몸통을 앞으로 구부렸고, 양손의 중지로 측정기를 천천히 밀었다. 감지시스템을 통해 2 회 반복한 평균값을 $\mathrm{cm}$ 단위로 산출하였으며, 기준점에 미치지 못했을 때에는 “-"값으로 기 록되었다.

\section{3) 근육경직도}

넙다리곧은근, 넙다리두갈래근, 넙다리근막긴장근의 경직도는 MyotonPRO로 측정하였다(Myoton AS, Estonia). 장비에 내장되어 있는 원 형탐침이 측정근육의 표면과 수직관계를 형성하게 되면 동일한 강도 의 기계적 자극이 피하조직에 가해지는데, 이때 발생한 진동, 가속도, 그리고 복원능력에 기초하여 경직도를 산출한다. 한 번 측정할 때 10 회의 기계적 자극이 주어지고 평균값을 계산하는 멀티스캔 모드로 설정되어 있으며, 변동계수 $3 \%$ 초과 시 적색의 경고신호가 나타나기 때문에 재측정하여 결과값의 정확도를 높일 수 있다. ${ }^{1920}$ 신체의 다양 한 부위에 적용 가능하고 신속 정확하게 결과값을 도출할 수 있으며, 높은 수준의 신뢰도가 보고된 바 있다(ICC 0.99). ${ }^{20}$ 모든 대상자는 치 료용 침대에 누워 10 분 동안 휴식을 취한 후 측정하였다. 해당 근육의 근육힘줄연결부위를 마커 펜으로 표시하였으며, 넙다리곧은근과 넙 다리근막긴장근은 바로 누운자세에서, 넙다리두갈래근육은 엎드린 자세에서 측정하였다.

\section{3. 실험절차}

2018 시즌 중반 K축구협회에서 지도자를 대상으로 본 연구의 절차와 부상예방 프로그램에 대해 소개하는 시간을 가졌다. 자발적으로 참 가의사를 밝힌 13 개팀 중 선정기준에 부합되는 3 개팀을 선발하였으 며, 한 팀에 소속된 축구선수 20 명을 동일한 연구집단에 배정하였다. 복합훈련 집단과 $11+$ 훈련 집단에 속한 지도자와 선수는 본격적인 훈 련이 시작되기 이전 $\mathrm{A}$ 대학교에서 진행한 워크숍에 참석하여 훈련방 법에 관한 이론 및 실기 교육을 받았으며, 프로그램의 운동동작이 시 연되어 있는 교육영상과 사진자료를 제공받았다. 일반훈련 집단은 해당 팀에서 시행되어 왔던 웜업 프로그램을 지속하였는데, 프로그 램에 포함된 운동항목은 $11+$ 및 자가근막이완과 중복되는 것이 없었 다. 12 주 동안 전향성 조사방식으로 연구대상자의 부상실태를 파악 하였고, 유연성 및 근육경직도는 사전사후 방식으로 측정한 후 비교 분석하였다.

웜업 운동은 12 주 동안 하루 40 분 주 3 회 적용하였으며, 훈련방법 에 숙달된 물리치료사 1 명과 선수트레이너 2 명이 팀의 훈련 프로그램 을 주 1 회 감독하여 정확한 방법으로 수행될 수 있도록 독려하였다. 또한 피파 11+ 프로그램이 포함된 훈련집단은 공식 및 연습 경기 전 웜업 시간에 피파 $11+$ 의 달리기 운동방법을 실행하도록 지도자에게 요청하였다.

1) 피파 $11+$

피파 $11+$ 프로그램은 15 종류의 운동방법을 3 개 파트로 구분하여 제 시하고 있다. 6 가지 동작으로 구성된 첫 번째 파트는 느린 속도의 달 리기와 능동신장 및 동료와의 신체접촉이 허용된 운동 등을 포함하 고 있으며, 동작 당 2 회 반복한다. 두 번째 파트는 균형, 중심근력, 다 리근력, 그리고 민첩성과 플라이오메트릭에 중점을 둔 6 가지 동작으 로 구성되어 있으며, 9번 동작을 제외한 나머지는 동작 당 유지시간 30 초 6 회 반복하였다. 마지막 파트는 3가지 종류의 운동방법으로 빠 른 속도달리기와 착지 및 방향전환 동작 등이 포함되어 있으며, 동작 당 2 회 반복한다. 운동강도는 두 번째 파트에서만 점진적으로 증가하 였는데, 레벨 1은 1-4주차까지, 레벨 2는 5-8주차, 레벨 3은 9-12주차에 실시하였다. 피파 $11+$ 프로그램 수행 시 가장 중요한 사항은 모든 운 동을 실시하는 동안 적합한 신체정렬상태와 자세조절능력이 발휘되 어야 한다는 것이다. 이를 위해 염두 할 사안은 다리는 항상 곧게 뻗 어 1 자를 만들고, 선 자세에서 다리를 구부릴 경우 무릎이 발끝을 넘 어가지 않게 하며, 착지동작을 수행할 때에는 충격을 최소화하기 위 해 무릎을 구부려 부드럽게 착지하는 것이다. 총 수행시간은 20-25분 이었다. ${ }^{2}$ 
Table 2. Comparison of injury incidence and severity in three groups

\begin{tabular}{lcccc}
\hline & CTG & $11+$ TG & TTG & $F$ \\
\hline Matches $(n)$ & 26 & 28 & 26 & \\
All injuries (n) & 43 & 64 & 72 & \\
$\quad$ injuries per match & $1.65 \pm 1.20^{b}$ & $1.93 \pm 1.30^{c}$ & $2.77 \pm 0.91$ & $6.631^{*}$ \\
Time-loss injuries (n) & 15 & 18 & 27 & \\
injuries per match & $0.58 \pm 0.86$ & $0.64 \pm 0.95$ & $1.04 \pm 1.04$ & 1.802 \\
Duration of time loss & & & & \\
0 days & $28(65 \%)$ & $36(67 \%)$ & $45(63 \%)$ & \\
1-3 days (minimal) & $8(19 \%)$ & $12(22 \%)$ & $15(21 \%)$ & \\
4-7 days (mild) & $6(14 \%)$ & $5(9 \%)$ & $7(10 \%)$ & \\
8-28 days (moderate) & $1(2 \%)$ & $1(2 \%)$ & $5(7 \%)$ & \\
$>$ 29 days (severe) & $0(0 \%)$ & $0(0 \%)$ & $0(0 \%)$ & \\
\hline
\end{tabular}

Mean \pm SD

CTG: Complex Training Group, 11+TG: 11+ Training Group, TTG: Traditional Training Group.

aSignificant difference between CTG and 11+TG, bSignificant difference between CTG and TTG, 'Significant difference between 11+TG and TTG. ${ }^{*} p<0.05$.

\section{2) 자가근막이완}

자가근막이완은 폴리프로필렌 재질로 제작된 길이 $30 \mathrm{~cm}$, 지름 15 $\mathrm{cm}$ 의 폼롤러를 이용하여 시행되었다(Blackroll, Germany). ${ }^{14}$ 바로 누 운자세에서는 몸통 뒤쪽. 볼기.넙다리 뒤쪽. 종아리 부위를 이완하 였고, 엎드린 자세에서는 넙다리 앞쪽과 정강이, 옆으로 누운 자세에 서는 몸통 및 넙다리의 옆쪽을 실시하였다. ${ }^{13}$ 폼롤러의 동일한 롤링 속도를 구현하기 위해 분당 60 비트로 설정되어 있는 메트로놈을 활 용하였으며, 비트소리가 2 번 들릴 때까지 한쪽 방향으로의 롤링을 시 도하여 60 초 동안 15 회의 롤링 움직임이 일어나도록 하였다. ${ }^{14}$ 압력강 도는 대상자의 체중에 의해 자가조절 되었는데, 수치평가척도(numerical rating scale, NRS) 7점 수준을 유지하도록 요청하였다. ${ }^{14}$ 모든 부위는 좌우 1 회 60 초씩 진행되었으며, 총 수행시간은 15-17분이었다.

\section{4. 자료분석}

본 연구에서 얻은 모든 자료는 Window용 SPSS 21.0 프로그램을 이용 하여 통계처리하였고, 연구대상자의 일반적 특성은 빈도분석과 기술 통계를 사용하였다. Shapiro-Wilk 방법을 활용하여 정규성을 검정하 였고, 모든 자료가 정규분포를 형성하였다. 경기당 부상율의 집단 간 차이는 일원분산분석, 부상발생 및 부상정도는 빈도분석을 실시하 였다. 집단 내 훈련 전. 후 유연성, 근육경직도의 개선여부를 알아보 기 위해 대응표본 t-검정을 활용하였으며, 집단 간 훈련 전· 후 변화량 의 차이는 일원분산분석으로 확인하였다. 통계학적 유의성이 발생 할 경우 터키(Tukey) 방법으로 사후검증을 실시하였으며, 통계학적 가설검정을 위한 유의수준은 0.05 로 설정하였다.
Table 3. Comparison of changes in three groups before and after training on hamstring muscle flexibility $(\mathrm{cm})$

\begin{tabular}{lcccc}
\hline & CTG & $11+T G$ & TTG & $F$ \\
\hline pre & $6.04 \pm 3.45$ & $6.16 \pm 2.04$ & $6.15 \pm 3.16$ & 0.011 \\
post & $8.27 \pm 2.77^{*}$ & $6.35 \pm 2.09$ & $7.45 \pm 2.46^{*}$ & 3.090 \\
$\mathrm{t}$ & -6.059 & -0.885 & -3.615 & \\
change & $2.23 \pm 1.65^{\mathrm{a}}$ & $0.19 \pm 0.93$ & $1.30 \pm 1.60^{\circ}$ & $10.224^{*}$ \\
\hline
\end{tabular}

Mean \pm SD.

CTG: Complex Training Group, 11+TG: 11+ Training Group, TTG: Traditional Training Group.

aSignificant difference between CTG and 11+TG, bSignificant difference between CTG and TTG, significant difference between 11+TG and TTG. ${ }^{*} p<0.05$

\section{결 과}

\section{1. 부상}

경기당 부상률 및 부상정도에 관한 분석결과는 Table 2 와 같다. 부상 빈도는 복합훈련 집단 43 회, $11+$ 훈련 집단 54 회, 일반훈련 집단 72 회 로 집계되었으며, 경기당 부상률은 각각 $1.65 \cdot 1.92 \cdot 2.76$ 회에 해당한다. 세 집단 간의 통계학적인 유의성이 있어 터키 사후검정으로 분석한 결과, 복합훈련 집단과 $11+$ 훈련 집단은 일반훈련 집단 보다 경기당 부 상율이 유의하게 낮았다 $(\mathrm{p}<0.05)$.

\section{2. 유연성}

넙다리뒤근육 유연성 변화에 관한 집단 내, 집단 간 분석결과는 Table 3 과 같다. 훈련 전·후 넙다리뒤근육의 유연성은 복합훈련 및 일반훈 련 집단에서 유의하게 증가하였다 $(\mathrm{p}<0.05)$. 훈련 전· 후 넙다리뒤근 육의 유연성 변화는 세 집단 간의 통계학적인 유의성이 있어 터키 사 후검정으로 분석한 결과, 복합훈련 집단과 일반훈련 집단은 $11+$ 훈련 집단 보다 넙다리뒤근육의 유연성을 유의하게 증가시켰다 $(\mathrm{p}<0.05)$.

\section{3. 근육경직도}

넙다리곧은근.넙다리두갈래근.넙다리근막긴장근 좌우 경직도 차 이 변화에 관한 집단 내, 집단 간 분석결과는 Table 4 와 같다. 훈련 전. 후 복합훈련 집단은 모든 근육에서 좌우 경직도 차이가 유의하게 감 소하였으며 $(\mathrm{p}<0.05), 11+$ 훈련 집단은 넙다리곧은근에서만 유의한 변 화를 확인할 수 있었다 $(\mathrm{p}<0.05)$. 훈련 전·후 모든 근육의 좌우 경직 도 차이 변화는 세 집단 간의 통계학적인 유의성이 있어 터키 사후검 정으로 분석한 결과, 넙다리곧은근과 넙다리근막긴장근은 복합훈련 집단이 $11+$ 훈련 및 일반훈련 집단 보다, 넙다리두갈래근은 복합훈련 집단이 일반훈련 집단 보다 좌우 경직도의 차이를 유의하게 감소시 켰다 $(\mathrm{p}<0.05)$. 
Table 4. Comparison of changes in three groups before and after training on $R F, B F$, TFL muscle stiffness $(\mathrm{N} / \mathrm{m})$

\begin{tabular}{|c|c|c|c|c|}
\hline & CTG & $11+\mathrm{TG}$ & TTG & $\mathrm{F}$ \\
\hline \multicolumn{5}{|l|}{ RF } \\
\hline pre & $15.85 \pm 8.35$ & $15.50 \pm 5.11$ & $15.80 \pm 5.60$ & 0.017 \\
\hline post & $5.20 \pm 2.24^{\star}$ & $12.55 \pm 4.64^{*}$ & $13.20 \pm 4.80$ & 23.907 \\
\hline $\mathrm{t}$ & 5.272 & 2.139 & 1.374 & \\
\hline change & $-10.65 \pm 9.03^{a, b}$ & $-2.95 \pm 6.17$ & $-2.60 \pm 8.46$ & $6.494^{*}$ \\
\hline \multicolumn{5}{|l|}{$\mathrm{BF}$} \\
\hline pre & $21.05 \pm 8.09$ & $20.15 \pm 5.42$ & $19.25 \pm 4.79$ & 0.412 \\
\hline post & $11.85 \pm 5.57^{*}$ & $17.30 \pm 6.28$ & $19.20 \pm 5.14$ & 9.019 \\
\hline $\mathrm{t}$ & 3.821 & 1.912 & 0.032 & \\
\hline change & $-9.20 \pm 10.77^{b}$ & $-2.85 \pm 6.67$ & $-0.05 \pm 7.04$ & $6.282^{*}$ \\
\hline \multicolumn{5}{|l|}{ TFL } \\
\hline pre & $22.00 \pm 6.32$ & $23.05 \pm 8.29$ & $20.75 \pm 6.03$ & 0.549 \\
\hline post & $11.15 \pm 6.52^{*}$ & $20.40 \pm 7.71$ & $21.25 \pm 5.40$ & 14.373 \\
\hline $\mathrm{t}$ & 5.644 & 0.871 & -0.254 & \\
\hline change & $-10.85 \pm 8.60^{a, b}$ & $-2.65 \pm 13.60$ & $0.50 \pm 8.80$ & $6.125^{*}$ \\
\hline
\end{tabular}

Mean \pm SD.

CTG: Complex Training Group, 11+TG: 11+ Training Group, TTG: Traditional Training Group, RF: rectus femoris, BF: biceps femoris, TFL: tensor fascia latae. asignificant difference between CTG and 11+TG, 'bSignificant difference between CTG and TTG, significant difference between 11+TG and TTG. ${ }^{*} \mathrm{p}<0.05$.

\section{고 찰}

축구선수의 부상예방 및 경기력향상은 축구과학 분야의 주요 이슈 로 다뤄지고 있다. 이에 관해 국내외 연구가들은 다양한 배경지식과 접근방법을 가지고 축구선수에게 필요한 기초자료와 효과적인 훈련 프로그램을 제시하여 왔다. 본 연구 역시 성장기에 있는 고등학교 축 구선수가 부상으로 인해 선수생활을 끝내지 않고 우수한 경기력을 선보이며 성인선수로 도약하는데 기여하고자 하였다. 본 연구의 주요 결과는 12 주 동안의 복합훈련이 고등학교 축구선수의 부상, 유연성, 근육경직도 향상에 전반적인 긍정효과를 보였다. 이러한 결과는 본 연구에서 실시한 선수 및 지도자 대상 계몽교육과 운동실습이 현장 에서 적용 가능한 효과적인 접근방법이 될 수 있음을 시사하며, 축구 선진국과 다르게 선수트레이닝 전문가가 학원 축구팀에 배제되어 있 는 국내현실에서 선수의 부상예방 및 경기력향상을 도와줄 수 있는 실용적인 처치라 생각한다.

부상실태 조사의 주요 목적은 부상의 기전 및 유형 분석을 통해 예 방전략을 설계하고 실행하여 부상률을 감소시키는데 있다.' 1998년 이후 F-MARC는 국제축구연맹 주관 모든 공식대회 및 올림픽대회의 축구경기에서 부상 실태를 의무적으로 조사하였고, ${ }^{17}$ 점차 다른 종 목의 스포츠 협회와 국제올림픽위원회(International Olympic Committee, IOC)에서도 이러한 조사 체계를 받아들이게 됐다. 본 연구자 도 선행논문의 절차대로 연구를 실시하여 세 집단의 부상실태를 조
사한 결과, 경기당 부상율은 복합훈련 집단 1.65 회, $11+$ 훈련 집단 1.93 회, 일반훈련 집단 2.77 회로 복합훈련 및 $11+$ 훈련 집단은 일반훈련 집 단 보다 부상율이 유의하게 낮았으며, 통계학적으로 유의하진 않았 지만 복합훈련 집단은 $11+$ 훈련 집단 보다 $14.5 \%$ 낮은 발생률을 보였 다. 피파 11+ 프로그램은 근력강화, 균형향상, 신경근 조절능력 증진 을 이룰 수 있는 웜업 운동으로 $\mathrm{Al} \mathrm{Attar}$ 등른 이러한 운동요소가 부 상예방 효과를 설명할 수 있는 주요 기전이라 하였다. 그 중에서도 주 목해야 할 사안은 신경근 조절능력인데, 이는 정적 및 동적 움직임 동 안 다리관절의 좌우 대칭성과 적합한 정렬상태 유지에 집중하고 있 음을 의미하며 이러한 노력이 다리부상으로 이어질 수 있는 무릎관 절의 과도한 밖굽이(valgus)와 점프 후 착지 순간 무릎관절의 불충분 한 굽힘동작을 제어할 수 있다.21 따라서 피파 $11+$ 프로그램이 포함되 어 있는 복합훈련 및 $11+$ 훈련 집단은 선행연구에서처럼 경기당 부상 율을 저하시킬 수 있었다고 판단된다.

Witvrouw 등 22의 코호트 연구에서는 넙다리뒤근육 길이 단축이 축구선수의 좌상 위험도를 높일 수 있어 예방차원 측면에서 유연성 검사의 효용성을 강조하였으며, 넙다리뒤근육 좌상을 경험한 선수가 일반 선수 보다 유연성이 유의하게 낮은 것으로 보고하였다. 본 연구 의 넙다리뒤근육 유연성 검사결과는 복합훈련 집단과 일반훈련 집 단에서 훈련 전. 후 유의한 변화가 나타났다. 이와 같은 결과는 복합 훈련 집단의 자가근막이완 운동과 일반훈련 집단의 정적 스트레칭 운동이 영향을 미친 것으로 판단된다. 자가근막이완 운동은 근육 및 운동 수행력 저하 없이 유연성을 향상시킬 수 있는 효과적인 접근방 법으로 알려져 있다. ${ }^{23} \mathrm{Kim}$ 등 24 은 넙다리뒤근육 유연성에 대해 자가 근막이완 운동이 효과적이었음을 보고하였고, MacDonald 등23은 무 릎관절의 가동범위, Monteiro 등 25 은 엉덩관절의 가동범위 향상에 효 능이 있다고 하였다. 본 연구의 복합훈련 집단은 전신에 걸쳐 자가근 막이완 운동을 실시하였으며, 선행연구와 유사하게 넙다리뒤근육의 유연성을 증가시켰다. 따라서 격렬한 신체활동을 준비하기 위한 웜업 프로그램으로써 자가근막이완 운동은 활용되어야만 하며, 축구선 진국의 선수처럼 국내 경기장에서도 폼롤러 이용사례가 증가. 확산 되길 기대한다. 일반훈련 집단의 유연성 증가도 주목해야봐야 할 사 안이다. 일반훈련 집단의 웜업 프로그램이 $11+$ 및 자가근막이완 운동 과 중복되지 않도록 하기 위해 매주 지도자로부터 프로그램 구성항 목을 확인하였는데, 근육의 유연성을 증가시킬 수 있는 정적신장 운 동이 포함되어 있었다. 정적신장 운동은 근육의 최종 가동범위에서 일정시간 동안 특정 자세를 유지하는 방법으로 근육 길이를 늘리기 위해 적용한다. ${ }^{26}$ 이를 통해 근육의 과긴장, 통증완화, 혈액순환 증가, 심폐능력 향상뿐만 아니라 근육의 유착 방지 및 근 저항 감소를 통하 여 스포츠 상해를 예방하고 운동능력 향상에 도움을 준다. ${ }^{27}$ 이와 같 은 결과는 역동적 움직임과 근력, 그리고 운동조절에 초점을 두고 있 
는 11+ 프로그램의 보완사항을 암시하는 것으로 적정한 스트레칭 운 동이 $11+$ 웜업 프로그램에 포함될 것을 권고하는 바이다.

축구는 90 분 동안 젖산 역치 수준에 근접한 운동강도로 $10 \mathrm{~km}$ 이 상 움직이는 매우 격렬한 운동종목이다. ${ }^{28}$ 이와 같은 고강도 운동은 근육의 미세손상을 초래하여 지연성근육통(delayed onset muscle soreness, DOMS) 및 근육의 경직도를 증가시킬 수 있는데, ${ }^{29}$ 이러한 경 직도 증가는 운동선수의 부상을 야기할 수 있는 위험인자로 알려져 있다. ${ }^{30}$ 축구선수는 공의 소유권을 놓고 상대선수와의 경쟁에서 우위 를 점해야 하기 때문에 급작스런 방향전환 및 속도변화가 자주 발생 하고, 특정 패턴으로만 킥 동작을 수행하는 경향이 있다. ${ }^{31}$ 이와 같은 동작특성이 관절 및 연부조직에 과도한 스트레스를 부과하여 누적 성외상성 질환에 노출될 수 있고, 뼈대의 비대칭이 근육의 불균형으 로 이어져 또 다른 질환의 원인이 될 수 있다. ${ }^{32}$ 다시 말하자면 축구선 수의 편측성 활동이 초래하는 뼈대구조 정렬이상이 신체 한쪽 영역 에 스트레스를 비정상적으로 증가시킬 수 있다는 것이다. 따라서 동 일 근육의 좌우 경직도 차이를 확인하는 것은 부상위험 선수를 분류 하는데 있어 가치 있는 과정이라 여겨지며, 본 연구에서는 다리 주요 근육의 경직도를 측정하여 좌우 차이값의 변화추이를 살펴보았다. 그 결과 복합훈련 집단은 모든 근육에서 유의한 감소를 보였으며, 집 단 간 비교에서는 복합훈련 집단의 모든 근육이 다른 집단 보다 통계 학적인 유의성을 선보였다. 이상의 결과는 축구선수의 부상예방을 위하여 개발된 $11+$ 프로그램이 지니고 있는 한계점을 지적하고 있음 과 동시에 비교적 간단한 방법과 저렴한 비용으로 마사지 효과를 재 현할 수 있는 자가근막이완 운동의 장점을 부각시키고 있다. 이처럼 넙다리뒤근육의 유연성 증진뿐만 아니라 다리근육의 경직도 완화 및 좌우 차이감소에 효과적인 자가근막이완 운동은 축구선수의 신 체관리를 위하여 없어서는 안 될 중요한 운동방법이라 할 수 있다.

본 연구의 제한점은 고등학교 남자축구선수를 대상으로 실시하였 기 때문에 다른 성별, 연령, 종목에 일반화하기 어려우며, 각 집단의 윔업 프로그램을 연구자가 주1회 관리·감독하는 관계로 훈련군 집 단을 블라인드 처리하지 못하였다. 선수트레이닝 방법론에 전문화되 지 못한 코치가 대부분의 훈련을 주관하여 운동 프로그램의 질적수 준이 낮아질 수는 있지만 국내 아마추어 축구계의 실제 훈련환경을 재현한 장점이 있었다. 훈련집단의 웜업 운동은 여러 운동요소가 혼 합된 포괄적인 프로그램으로 이루어져 있기 때문에 개별요소의 효 과를 분할해서 설명하기 어려우며, 선행연구와 달리 3 개월의 짧은 기 간 동안만 진행되어 웜업 프로그램의 이점을 $100 \%$ 얻어내지 못했을 것이다. 추후 연구에서는 협회에 등록된 여러 팀을 섭외하여 최소 1 시즌 동안 군집무작위조절연구를 시도할 필요가 있고, 다양한 연령 및 성별을 대상으로 연구가 이루어져야 한다. 또한 하강점프, 사이드 스텝, 크로스컷팅과 같은 기능적인 움직임 동안 생체역학 연구를 통
해 검증된 위험요인들이 훈련 전·후 제어될 수 있는지 여부를 객관적 인 결과값으로 확인할 필요가 있다.

축구선수의 부상예방 및 경기력향상에 적합한 훈련 프로그램을 제시하는 것은 선수트레이닝 분야의 전문가가 역점을 두어야 할 부 분이라고 생각한다. 본 연구에서 피파 11+와 자가근막이완 복합훈련 은 고등학교 축구선수의 부상, 유연성, 근육경직도에 긍정적인 영향 을 미쳤다. 따라서 여러 운동요소가 혼합된 피파 $11+$ 프로그램과 자 가근막이완의 복합훈련은 현장에서 적용할 수 있는 유용한 웜업 방 법이라고 제언하는 바이다.

\section{REFERENCES}

1. Junge A, Dvorak J. Football injuries during the 2014 FIFA world cup. Br J Sports Med. 2015;49(9):599-602.

2. Bizzini M, Junge A, Dvorak J. The "11+" manual. Zurich, FIFA Medical Assessment and Research Centre, 2006:4.

3. Petersen J, Holmich P. Evidence based prevention of hamstring injuries in sport. Br J Sports Med. 2005;39(6):319-23.

4. Bahr R, Holme I. Risk factors for sports injuries-a methodological approach. Br J Sports Med. 2003;37(5):384-92.

5. Soligard T, Myklebust G, Steffen K et al. Comprehensive warm-up programme to prevent injuries in young female footballers: cluster randomised controlled trial. Bmj. 2008;337:a2469.

6. Owoeye OB, Akinbo SR, Tella BA et al. Efficacy of the FIFA 11+ warmup programme in male youth football: a cluster randomised controlled trial. J Sports Sci Med. 2014;13(2):321-8.

7. Silvers-Granelli H, Mandelbaum B, Adeniji O et al. Efficacy of the FIFA $11+$ injury prevention program in the collegiate male soccer player. Am J Sports Med. 2015;43(11):2628-37.

8. Daneshjoo A, Mokhtar AH, Rahnama N et al. The effects of injury preventive warm-up programs on knee strength ratio in young male professional soccer players. PLoS One. 2012;7(12):e50979.

9. Daneshjoo A, Mokhtar AH, Rahnama N et al. Effects of the $11+$ and harmoknee warm-up programs on physical performance measures in professional soccer players. J Sports Sci Med. 2013;12(3):489-96.

10. Rossler R, Donath L, Bizzini M et al. A new injury prevention programme for children's football-FIFA 11+ Kids-can improve motor performance: a cluster-randomised controlled trial. J Sports Sci. 2016;34 (6):549-56.

11. Zarei M, Abbasi H, Daneshjoo A et al. Long-term effects of the 11+ warm-up injury prevention programme on physical performance in adolescent male football players: a cluster-randomised controlled trial. J Sports Sci. 2018;36(21):2447-54.

12. Nawed A, Khan I, Jalwan J et al. Efficacy of FIFA 11+ training program on functional performance in amateur male soccer players. J Back Musculoskelet Rehabil. 2018;31(5):867-70.

13. Peacock CA, Krein DD, Silver TA et al. An acute bout of self-myofascial release in the form of foam rolling improves performance testing. Int J Exerc Sci. 2014;7(3):202-11.

14. Krause F, Wilke J, Niederer D et al. Acute effects of foam rolling on passive tissue stiffness and fascial sliding: study protocol for a randomized 
controlled trial. Trials. 2017;18(1):114.

15. Kim SD, Hong SH, Seo JN et al. The effect of self-myofascial release on elasticity and stiffness of fatigued rectus femoris muscle induced by isokinetic endurance exercise. Journal of Sport and Leisure Studies. 2016; 65:651-62.

16. Skarabot J, Beardsley C, Stirn I. Comparing the effects of self-myofascial release with static stretching on ankle range-of-motion in adolescent athletes. Int J Sports Phys Ther. 2015;10(2):203-12.

17. Junge A, Dvorak J, Graf-Baumann T et al. Football injuries during FIFA tournaments and the Olympic Games, 1998-2001: development and implementation of an injury-reporting system. Am J Sports Med. 2004; 32(1 Suppl):80-9.

18. Longo UG, Loppini M, Cavagnino R et al. Musculoskeletal problems in soccer players: current concepts. Clin Cases Miner Bone Metab. 2012;9 (2):107-11.

19. Aird L, Samuel D, Stokes M. Quadriceps muscle tone, elasticity and stiffness in older males: reliability and symmetry using the MyotonPRO. Arch Gerontol Geriatr. 2012;55(2):e31-9.

20. Mullix J, Warner M, Stokes M. Testing muscle tone and mechanical properties of rectus femoris and biceps femoris using a novel hand held MyotonPRO device: relative ratios and reliability. Work Pap Health Sci. 2012;1(1):1-9.

21. Al Attar WSA, Soomro N, Pappas E et al. Adding a post-training FIFA 11+ exercise program to the pre-training FIFA 11+ injury prevention program reduces injury rates among male amateur soccer players: a clusterrandomised trial. J Physiother. 2017;63(4):235-42.

22. Witvrouw E, Danneels L, Asselman P et al. Muscle flexibility as a risk factor for developing muscle injuries in male professional soccer players. Am J Sports Med. 2003;31(1):41-6.
23. MacDonald GZ, Penney MD, Mullaley ME et al. An acute bout of selfmyofascial release increases range of motion without a subsequent decrease in muscle activation or force. J Strength Cond Res. 2013;27(3): 812-21.

24. Kim DH, Kim TH, Jung DY et al. Effects of the graston technique and self-myofascial release on the range of motion of a knee joint. J Korean Soc Phys Med. 2014;9(4):455-63.

25. Monteiro ER, Vigotsky AD, Novaes JDS et al. Acute effects of different anterior thigh self-massage on hip range-of-motion in trained men. Int J Sports Phys Ther. 2018;13(1):104-13.

26. Puentedura EJ, Huijbregts PA, Celeste S et al. Immediate effects of quantified hamstring stretching: Hold-relax proprioceptive neuromuscular facilitation versus static stretching. Phys Ther Sport. 2011;12(3):122-6.

27. Park HY, Lee MM. A comparison of the effect of stretching technique on hamstring muscle for flexibility, strength, pressure pain threshold value and muscle tone. J Korean Soc Phys Med. 2017;12(4):39-46.

28. Stolen T, Chamari K, Castagna C et al. Physiology of soccer. Sports Medicine. 2005;35(6):501-36.

29. Pearcey GE, Bradbury-Squires DJ, Kawamoto JE et al. Foam rolling for delayed-onset muscle soreness and recovery of dynamic performance measures. J Athl Train. 2015;50(1):5-13.

30. Sherer E. Effects of utilizing a myofascial foam roll on hamstring flexibility. Eastern Illinois University. Dissertation of Master's Degree. 2013.

31. Tscholl P, O'Riordan D, Fuller CW et al. Causation of injuries in female football players in top-level tournaments. Br J Sports Med. 2007;41(1 Suppl):i7-13.

32. Chun SY. The effects of soccer on trunk and pelvic inclination, imbalance and rotation in male college student. Journal of Football Science. 2015;5:23-30. 